\title{
The Impact of Voluntary Disclosure and Accounting Earnings Quality on the Company Value in Listed of Iraqi Companies
}

\author{
Bushra Abdul Wahab Aljawaheri and Haider Mohamed Shrshab \\ Department of Accounting, College of Administration and Economics, \\ University of Kufa, Kufa, Iraq
}

\begin{abstract}
This study aimed to exam the impact of voluntary disclosure and accounting earnings quality on company value of listed companies in Iraqi Stock Exchange. The study methodology was a pooled data collected from the Iraqi Stock Exchange for the period from 2009-2015. The study sample is 17 listed banks using SPSS. The study independent variables are voluntary disclosure and accounting earnings quality. The dependent variable is company value which was measured using Tobin's $Q$. The study also utilized (size, age, financial leverage, return on stockholders and market value to book of share) as control variables in order to help measuring the relationship among voluntary disclosure, accounting earnings quality and company value. The results of the study indicated that there is significant impact for voluntary disclosure and accounting earnings quality on company value. By testing the impact of voluntary disclosure the study recommends adopting a full reviewing on measuring of voluntary disclosure to increase the company value from users in Iraqi Stock Exchange. In addition, higher level of voluntary disclosure provides future information and risk indicators voluntarily.
\end{abstract}

Key words: Voluntary disclosure, accounting earnings quality, company value, Iraqi companies, stock exchange, financial leverage

\section{INTRODUCTION}

In competitive environment, information is considered an important tool for making financing and investing decisions. The quality of decisions depends upon the significant of reported information in financial statements (Jamkarani and Hozi, 2016). Management will try to present enhanced voluntary information in order to maximize disclosure and presenting advantages (Almagtome et al., 2017). For this needing the accounting literature started to review in the full accounting process determining, measuring and reporting for willing the challenges in the modern environment. One of new approaches to develop the financial statements is voluntary disclosure that may reduce the level of information asymmetry (Farook et al., 2011). Voluntary disclosure provides many benefits for company including low capital cost, high trust of investors, improving of shares value (Cooke, 1992).

According to Dechow et al. (2010), the reported earnings of abnormal items lead to decrease an accounting earnings quality even it prepared accordance to general accepting accounting principles. The companies that have a quality of earnings tend to extend more in voluntary accounting disclosure. With improve firm performance and employees generate a good idea about the operations level and firm ability (Francis et al., 2008).

This study aims to investigate the impact of voluntary disclosure and accounting earnings quality on company value and to explain empirically the differences without and within the voluntary disclosure and accounting earnings quality on company value.

Literature review: Users are proficient and understand the information that will affect on their decisions, the financial and nonfinancial information that reported by companies are an important tools increase/decrease current and future investors/stockholders. Moreover, the extension in accounting disclosure about some items could volunteer support the certain and a better distribution of available resources that reduce the risks and capital costs to growth a company value. The last global crisis showed a big problem in accounting disclosure because the financial statement did not serve users specially stockholders (Verrecchia, 2001). Mutiva et al. (2015) examined the relationship between voluntary disclosure and firm performance in Nairobi

Corresponding Author: Bushra Abdul Wahab Aljawaheri, Department of Accounting, College of Administration and Economics, University of Kufa, Kufa, Iraq 
securities exchange by 10 companies from 2011-2013. Results indicated when companies have voluntary disclosure the performance will be good that supports the trust of investors for making decisions. The integrating of voluntary disclosure and earnings quality is investigated positively even it will report on weakness of internal control because this indexing helps to provide additional and useful information for users ( $\mathrm{Ji}$ et al., 2017). On the contrary, Consoni et al. (2017) found the relationship between voluntary disclosure and earnings management is negative using Dechow et al. (1995) model in Brazilian companies. The firms do not interest for voluntary disclosure sufficiently that allows extremely to use asymmetry information for earnings management. According to Almagtome et al. (2017), the voluntary disclosure positively and significantly associated with earnings level and leaded to improve the financial performance of firms.

However, the earnings quality has an important role to support investment efficiency that creates a perfect idea about the company performance and earnings for investment opportunity (Cherkasova and Rasadi, 2017). Kothari et al. (2005) model used to calculate voluntary accruals as alternative variable for measuring accounting earnings quality. Financial performance has mediated affect between corporate governance and firm value that shows the indirect effects on firm value. Results presents no significant effect of corporate governance on firm value directly but it is indirectly by financial performance (Paminto, 2015). Nyamongo (2017) evidenced the significant association between voluntary disclosure and company value in Kenya using Tobin's Q Model. The findings showed that voluntary disclosure helps to decrease the gap between investors and stockholders. Finally, recommended that voluntary disclosure should be as index information value for population. Hence, the study summarize hypothesis as follow:
- $\mathrm{H}_{1}$ : the voluntary disclosure has positively affected on company value

- $\mathrm{H}_{2}$ : accounting earnings quality has positively affected on company value

- $\mathrm{H}_{3}$ : accounting earnings quality and voluntary disclosure has significantly affected on company value

\section{MATERIALS AND METHODS}

Sampling: The study has used banks sector of Iraqi Exchange by 22 banks for 7 years (2009-2015), data included the variables study (voluntary disclosure, accounting earnings quality and company value). The study deleted 5 banks because they have different accounting system and have not full data. Finally, the banks had depended are 17 as in Table 1 .

Study models: The 3 different measures are used for research variables (independent, dependent, control). Voluntary disclosure and accounting earnings quality are independent. Company value is dependent. Size, age, financial leverage, return on stockholders and market value to book of share are control (Cooke, 1992, Mendes-Da-Silva and de Lira, 2004; Abdelghany, 2005; Lieberman and Balasubramanian, 2007):

- Voluntary disclosure: has measured by degrees (0-1), set value of 1 when company has disclosure and set value of 0 otherwise

- Accounting earnings quality has measured from Abdelghany (2005) Model by mean equation

$$
\mathrm{ATC}=\left(\mathrm{Earn}_{\mathrm{it}} / \mathrm{TA}_{\mathrm{it}-1}\right) \div\left(\mathrm{CFO}_{\mathrm{it}} / \mathrm{TA}_{\mathrm{it}-1}\right)
$$

- Company value: has measured from Tobin's Q Model by divided the market value of shares on book value of assets

Table 1: General data of study sample

\begin{tabular}{llll}
\hline Bank names & Starting date & Consideration date & Capital \\
\hline Gulf Commercial Bank & $20 / 10 / 1999$ & $25 / 7 / 2004$ & 300000000000 \\
Ashore Bank & $25 / 4 / 2005$ & $11 / 11 / 2007$ & 250000000000 \\
Mansour Bank for Investment & $13 / 9 / 2005$ & $1 / 7 / 2008$ & 250000000000 \\
Baghdad Bank & $18 / 2 / 1992$ & $15 / 5 / 2004$ & 250000000000 \\
Middle East Bank for Investment & $7 / 7 / 1993$ & $7 / 8 / 2004$ & 250000000000 \\
National Bank & $2 / 1 / 1995$ & $8 / 7 / 2004$ & 250000000000 \\
Union Bank & $23 / 9 / 2002$ & $30 / 10 / 2006$ & 252000000000 \\
United Bank for Investment & $20 / 8 / 1994$ & $3 / 2 / 2009$ & 300000000000 \\
Credit Bank & $25 / 7 / 1995$ & $8 / 7 / 2004$ & 250000000000 \\
North Bank for Financing and Investing & $7 / 10 / 2003$ & $1 / 9 / 2006$ & 300000000000 \\
Kurdistan Bank for Investment & $13 / 3 / 2005$ & $1 / 11 / 2006$ & 400000000000 \\
Trade Bank & $11 / 2 / 1992$ & $25 / 7 / 2004$ & 260000000000 \\
Investing Bank & $13 / 7 / 1993$ & $15 / 6 / 2004$ & 250000000000 \\
Mosul Bank for Development and Investment & $23 / 8 / 2001$ & $1 / 9 / 2005$ & 252500000000 \\
Baby lon Bank & $6 / 4 / 1999$ & $8 / 7 / 2004$ & 236859273334 \\
Dar Essalaam Bank for Investment & $7 / 12 / 1998$ & $15 / 6 / 2004$ & 150000000000 \\
Summer Commercial Bank & $26 / 5 / 1999$ & $4 / 9 / 2004$ & 250000000000 \\
\hline
\end{tabular}


- Company size: has measured from a nature logarithm of assets

- Company age: has measured by the curvy between starting and testing date

- Financial leverage: has measured by divided total liabilities on assets

- Return on stockholders: has measured by divided net profit on owner equity

- Market value to book of share: has measured by divided market value of share on book value

\section{RESULTS AND DISCUSSION}

Descriptive statistics: The descriptive results show that the mean index of accounting earnings quality for the period from 2009-2015 is $41.2 \%$ this means that more than half of Iraqi listed companies have accounting earnings quality indexes. Study found that the mean voluntary disclosure in Iraqi companies was $46.1 \%$ this percentage presents that the voluntary disclosure in Iraq is adopted for many managers and users. Results also found that $41.2 \%$ of depended companies improve the value of banks (Table 2).

The study checked the normal distribution for data that argues independent and dependent variables normally will help to test hypothesis as next step. The test of normal distribution has used by Kolmogorov-Smirnov test. Table 3 shows the results are significant, (Asymp. Sig. 2-tailed) are (0.209, 0.419 and $0.356, p<0.05)$ for voluntary disclosure, accounting earnings quality and company value.

Figure 1-3 show the points of value on normal line by predicted values and residual values for voluntary disclosure, accounting earnings quality and company value. Data are practically having a normal distribution.

Regression statistics: The main aim of study is determining the impact of voluntary disclosure and accounting earnings quality on company value.

Table 4 shows the results of $\mathrm{H}_{1}$ that exam the impact of voluntary disclosure on company value. Results support the hypothesis 1 that adjusted $\mathrm{R}^{2}$ is $21 \%$, the model is significant $(p<0.001)$ level. The voluntary disclosure on company value. The coefficient of voluntary disclosure is positive (0.34) and significantly different from zero at the $1 \%$ (t-statistics 3.359). The increasing in company value is $0.34 / 1 \%$ increase in voluntary disclosure. In addition, F-value significantly is accepted a testing higher than scheduled value (6. 296 $>2.244, \mathrm{p}<0.001$ ). Thus, consistent with hypothesis 1 (the voluntary disclosure has positively affected on company value).
Table 2: Descriptive statistics

\begin{tabular}{|c|c|c|c|c|c|}
\hline Variables & $\mathrm{N}$ & Minimum & Maximum & Mean & $\mathrm{SD}$ \\
\hline $\begin{array}{l}\text { Accounting earnings } \\
\text { quality }\end{array}$ & 119 & 0.01 & 0.92 & 0.4128 & 0.23548 \\
\hline Company value & 119 & 0.110 & 0.910 & 0.41227 & 0.155979 \\
\hline Voluntary & 119 & 0.13 & 0.82 & 0.4618 & 0.16014 \\
\hline Size & 119 & 94982200 & 1827505325 & 5.56 & 3.607 \\
\hline Financial leverage & 119 & 0.244 & 0.876 & 0.59978 & 0.155607 \\
\hline Age & 119 & 40 & 275 & 158.18 & 60.145 \\
\hline RET & 116 & 0.002 & 0.206 & 0.08067 & 0.052041 \\
\hline MTB & 119 & 0.22 & 3.83 & 1.0875 & 0.57255 \\
\hline
\end{tabular}

Table 3: One-sample Kolmogorov-Smirnov test

\begin{tabular}{llll}
\hline Variables & $\begin{array}{l}\text { Accounting } \\
\text { earnings quality }\end{array}$ & $\begin{array}{l}\text { Company } \\
\text { values }\end{array}$ & $\begin{array}{l}\text { Voluntary } \\
\text { disclosure }\end{array}$ \\
\hline $\mathrm{N}$ & 119 & 119 & 119 \\
$\begin{array}{l}\text { Normal parameters }{ }^{\mathrm{a}, \mathrm{b}} \\
\text { Mean }\end{array}$ & 0.4128 & 0.41227 & 0.4618 \\
$\mathrm{SD}$ & 0.23548 & 0.155979 & 0.16014 \\
Most extreme differ ences & & & \\
Absolute & 0.081 & 0.085 & 0.097 \\
Positive & 0.081 & 0.085 & 0.073 \\
Negative & -0.057 & -0.052 & -0.097 \\
Kolmogorov-Smirnov Z & 0.881 & 0.927 & 1.062 \\
Asymp. Sig. (2-tailed) & 0.419 & 0.356 & 0.209 \\
\hline
\end{tabular}

${ }^{a}$ Test distribution is normal; ${ }^{b}$ Calculated from data

Table 5 shows the results of $\mathrm{H}_{2}$ that exam the impact of accounting earnings quality on company value. Results support the $\mathrm{H}_{2}$ that adjusted $\mathrm{R}^{2}$ is $16 \%$, the model is significant $(\mathrm{p}<0.001)$ level. The accounting earnings quality on company value. The coefficient of accounting earnings quality is positive (0.15) and significantly different from zero at the $1 \%$ (t-statistics 2.618). The increasing in company value is $0.15 \%$ per $1 \%$ increase in accounting earnings quality. In addition, F-value significantly is accepted a testing higher than scheduled value (4. $708>2.244, \mathrm{p}<0.001)$. Thus, consistent with $\mathrm{H}_{2}$ (accounting earnings quality has positively affected on company value).

Table 6 shows the results of $\mathrm{H}_{3}$ that exam the impact of accounting earnings quality and voluntary disclosure on company value. Results support the $\mathrm{H}_{3}$ that adjusted $\mathrm{R}^{2}$ is $21 \%$, the model is significant $(\mathrm{p}<0.001)$ level. The accounting earnings quality and voluntary disclosure on company value. The coefficient of accounting earnings quality is positive (0.055) and significantly different from zero at the $1 \%$ (t-statistics 0.533 ), the coefficient of voluntary disclosure is positive $(0.295)$ and significantly different from zero at the $1 \%$ (t-statistics 2.871). The increasing in company value is $0.5 / 1 \%$ increase in accounting earnings quality and it is $0.29 / 1 \%$ increase in voluntary disclosure. In addition, F-value significantly is accepted a testing higher than scheduled value $(5.482>2.244, \mathrm{p}<0.001)$. Thus, consistent with $\mathrm{H}_{3}$ (accounting earnings quality and voluntary disclosure has significantly affected on company value). 


\section{J. Eng. Applied Sci., 14 (2): 623-628, 2019}

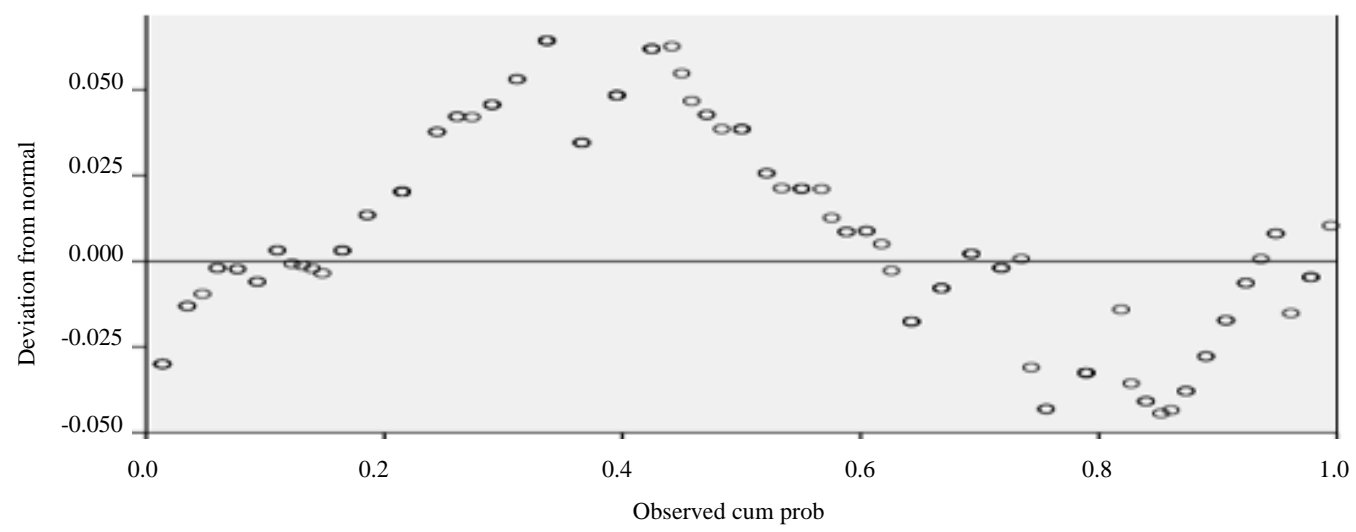

Fig. 1: Distributed values for accounting profits quality

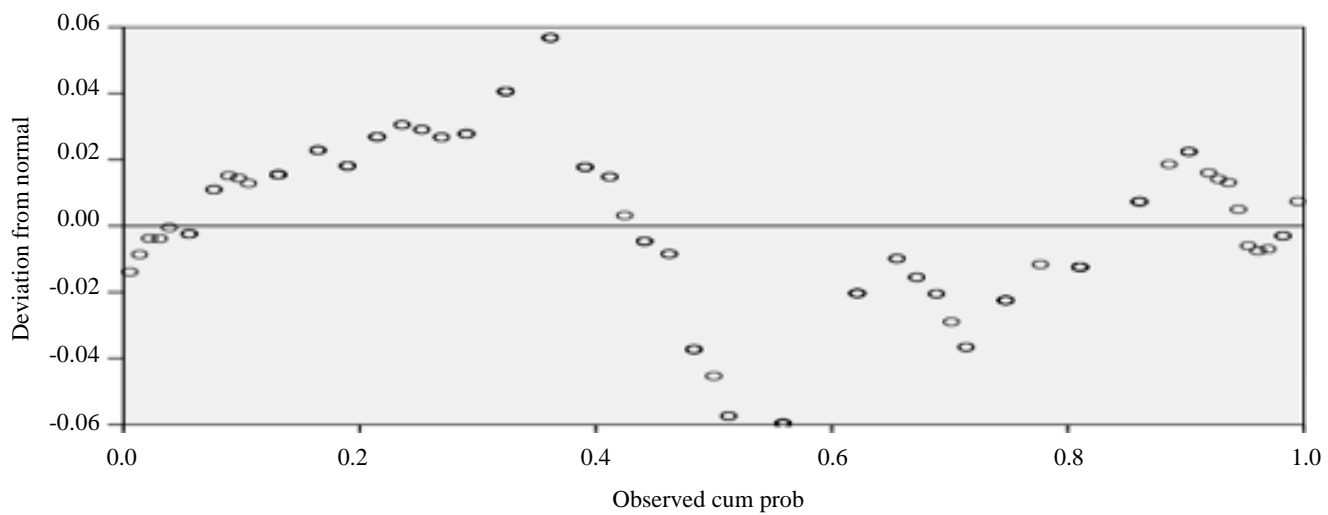

Fig. 2: Distributed values for voluntary disclosure

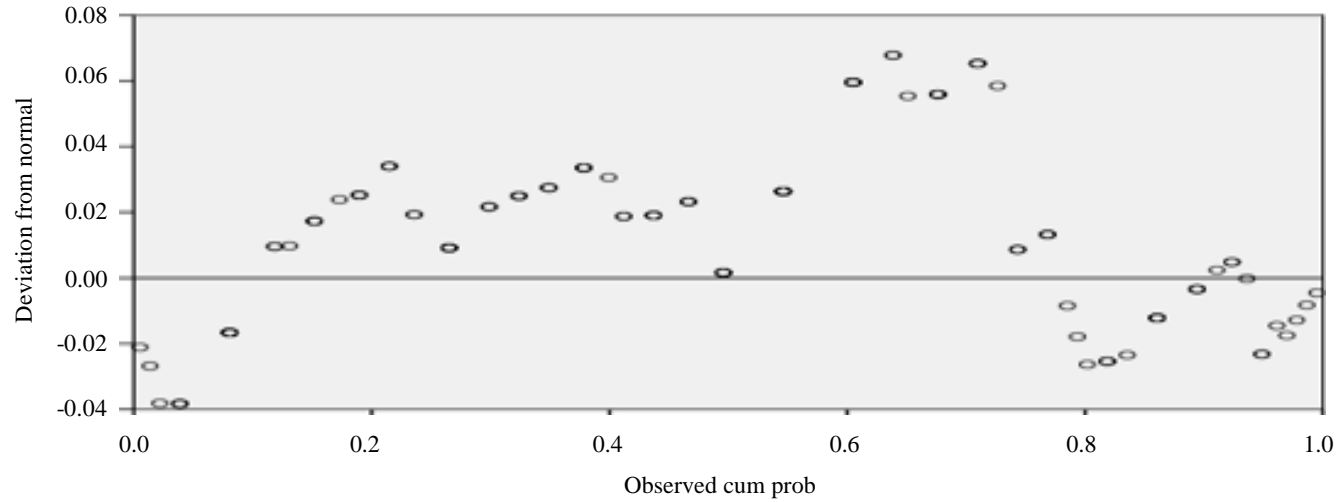

Fig. 3: Distributed values for compony value

Table 4: The effect of voluntary disclosure on company value

\begin{tabular}{|c|c|c|c|c|c|c|c|}
\hline \multirow[b]{2}{*}{ Models } & \multirow[b]{2}{*}{ Unstandardized coefficients (B) } & \multirow[b]{2}{*}{ Standardized coefficients $(\beta)$} & \multirow[b]{2}{*}{ SE } & \multirow[b]{2}{*}{ t-values } & \multirow[b]{2}{*}{ Sig. } & \multicolumn{2}{|c|}{ Collinearity statistics } \\
\hline & & & & & & Tolerance & VIF \\
\hline (Constant) & 0.284 & & 0.079 & & 3.616 & 0.000 & \\
\hline $\mathrm{VD}_{\text {it }}$ & 0.340 & 0.353 & 0.088 & 3.859 & 0.000 & 0.814 & 1.228 \\
\hline SIZE $_{\text {it }}$ & -0.001 & -0.253 & 0.000 & -2.463 & 0.015 & 0.645 & 1.549 \\
\hline $\mathrm{LEV}_{\text {it }}$ & -0.215 & -0.216 & 0.117 & -1.838 & 0.069 & 0.491 & 2.035 \\
\hline $\mathrm{AGE}_{\mathrm{it}}$ & -0.0065 & -0.026 & 0.000 & -0.285 & 0.776 & 0.845 & 1.183 \\
\hline $\mathrm{RET}_{\text {it }}$ & 0.057 & 0.019 & 0.298 & 0.191 & 0.849 & 0.670 & 1.493 \\
\hline MTB $_{\text {it }}$ & 0.154 & 0.569 & 0.030 & 5.113 & 0.000 & 0.551 & 1.816 \\
\hline
\end{tabular}

Adjusted $\mathrm{R}^{2}=0.2160 ; \mathrm{F}$-value $=6.296^{\text {***** }}$ 
Table 5: The effect of accounting earnings quality on company value

\begin{tabular}{|c|c|c|c|c|c|c|c|}
\hline \multirow[b]{2}{*}{ Models } & \multirow[b]{2}{*}{ Unstandardized coefficients (B) } & \multirow[b]{2}{*}{ Standardized coefficients $(\beta)$} & \multirow[b]{2}{*}{$\mathrm{SE}$} & \multirow[b]{2}{*}{ t-values } & \multirow[b]{2}{*}{ Sig. } & \multicolumn{2}{|c|}{ Collinearity statistics } \\
\hline & & & & & & Tolerance & VIF \\
\hline (Constant) & 0.411 & & 0.069 & 5.987 & 0.000 & & \\
\hline $\mathrm{APQ}_{\mathrm{it}}$ & 0.152 & 0.230 & 0.058 & 2.618 & 0.010 & 0.941 & 1.063 \\
\hline $\mathrm{SIZE}_{\text {it }}$ & -0.006 & -0.154 & 0.000 & -1.506 & 0.135 & 0.701 & 1.427 \\
\hline $\mathrm{LEV}_{\text {it }}$ & -0.260 & -0.262 & 0.121 & -2.140 & 0.035 & 0.487 & 2.053 \\
\hline $\mathrm{AGE}_{\text {it }}$ & -0.009 & -0.039 & 0.000 & -0.415 & 0.679 & 0.846 & 1.182 \\
\hline $\mathrm{RET}_{\text {it }}$ & 0.087 & 0.029 & 0.309 & 0.281 & 0.779 & 0.667 & 1.498 \\
\hline $\mathrm{MTB}_{\mathrm{it}}$ & 0.129 & 0.475 & 0.030 & 4.319 & 0.000 & 0.603 & 1.659 \\
\hline
\end{tabular}

Adjusted $\mathrm{R}^{2}=0.162 ; \mathrm{F}$-value $=4.708^{* * * *}$

Table 6: The effect of accounting eamings quality and voluntary disclosure on company value

\begin{tabular}{|c|c|c|c|c|c|c|c|}
\hline \multirow[b]{2}{*}{ Models } & \multirow[b]{2}{*}{ Unstandardized coefficients (B) } & \multirow[b]{2}{*}{ Standardized coefficients $(\beta)$} & \multirow[b]{2}{*}{$\mathrm{SE}$} & \multirow[b]{2}{*}{$t$-values } & \multirow[b]{2}{*}{ Sig. } & \multicolumn{2}{|c|}{ Collinearity statistics } \\
\hline & & & & & & Tolerance & VIF \\
\hline (Constant) & 0.289 & & 0.079 & 3.667 & 0.000 & & \\
\hline $\mathrm{APQ}_{\text {it }}$ & 0.055 & 0.083 & 0.101 & 0.533 & 0.045 & 0.691 & 1.448 \\
\hline $\mathrm{VD}_{\text {it }}$ & 0.295 & 0.307 & 0.103 & 2.871 & 0.005 & 0.598 & 1.672 \\
\hline $\mathrm{SIZE}_{\text {it }}$ & -1.027 & -0.243 & 0.000 & -2.348 & 0.021 & 0.637 & 1.570 \\
\hline $\mathrm{LEV}_{\text {it }}$ & -0.228 & -0.230 & 0.118 & -1.929 & 0.056 & 0.483 & 2.071 \\
\hline $\mathrm{AGE}_{\text {it }}$ & $-6.960 \mathrm{E}-5$ & -0.028 & 0.000 & -0.307 & 0.760 & 0.844 & 1.184 \\
\hline $\mathrm{RET}_{\text {it }}$ & 0.036 & 0.012 & 0.299 & 0.119 & 0.906 & 0.665 & 1.504 \\
\hline MTB $_{\text {it }}$ & 0.154 & 0.569 & 0.030 & 5.108 & 0.000 & 0.551 & 1.816 \\
\hline
\end{tabular}

Adjusted $\mathrm{R}^{2}=0.214 ; \mathrm{F}$-value $=5.482^{* * * * *}$

\section{CONCLUSION}

The main goal of the study is to investigate the impact of voluntary disclosure and accounting earnings quality on company value through the Iraqi listed companies. The study aims to measure the impact of the benefits on disclosure and performance quality in Iraqi banks. This study provides an empirical testing of the voluntary disclosure, accounting earnings quality and company value model. Including the level in reported information, earnings, cash flows and market values. It adds a new dimension to theory of disclosure by examination the effect of voluntary disclosure and accounting earnings quality on company value. Therefore, we argue that the right company application needs to study voluntary disclosure and accounting earnings quality together. Also, companies value have growth positively for operational reasons because when they have high level of earning quality like to report more information voluntarily. Moreover, the study presented new empirical evidence combination the theory of value management and disclosure from financial accounting to develop practical hypothesis because this issue creates a big optimism or pessimism about future position.

The study raises the questions about the level of voluntary disclosure adoption and the impact of voluntary disclosure practices on company value using a sample of 17 Iraqi listed companies. Data was collected from Iraqi Stock Exchange database. The data included the financial information of the year 2009-2015. Voluntary disclosure which is level of reported information (performance, risk and others), accounting earnings quality which is percentage of earnings on operational cash and company value which is Tobin's Q. Voluntary disclosure and accounting earnings quality as independent variables, company value is used as dependent variable. Validation investigations confirm that our practical results for voluntary disclosure adoption, a linear effect of levels in disclosure and earnings quality, is separated from company performance and value. Many literature examined the relationship between voluntary disclosure and company value without reasons of earnings quality.

\section{REFERENCES}

Abdelghany, K.E., 2005. Measuring the quality of earnings. Managerial Auditing J., 20: 1001-1015.

Almagtome, A., I. Almusawi and K. Aureaar, 2017. Challenges of corporate voluntary disclosures through the annual reports: Evidence from Iraq. World Applied Sci. J., 35: 2093-2100.

Cherkasova, V. and D. Rasadi, 2017. Earnings quality and investment efficiency: Evidence from Eastern Europe. Rev. Econ. Perspect., 17: 441-468.

Consoni, S., R.D. Colauto and G.A.S.F.D. Lima, 2017. Voluntary disclosure and earnings management: Evidence from the Brazilian capital market. Rev. Contabilidade Financas, 28: 249-263. 
Cooke, T.E., 1992. The impact of size, stock market listing and industry type on disclosure in the annual reports of Japanese listed corporations. Account. Bus. Res., 22: 229-237.

Dechow, P., W. Ge and C. Schrand, 2010. Understanding earnings quality: A review of the proxies, their determinants and their consequences. J. Account. Econ., 50: 344-401.

Dechow, P.M., R.G. Sloan and A.P. Sweeney, 1995. Detecting earnings management. Accoun. Rev., 70: 193-225.

Farook, S., H.M. Kabir and R. Lanis, 2011. Determinants of corporate social responsibility disclosure: The case of Islamic banks. J. Islamic Accounting Bus. Res., 2: 114-141.

Francis, J., D. Nanda and P. Olsson, 2008. Voluntary disclosure, earnings quality and cost of capital. J. Account. Res., 46: 53-99.

Jamkarani, R.G. and T. Hozi, 2016. Relationship between the accrual-based earnings management and future financial performance. Intl. Bus. Manage., 10: 1013-1019.

Ji, X.D., W. Lu and W. Qu, 2017. Voluntary disclosure of internal control weakness and earnings quality: Evidence from China. Intl. J. Accounting, 52: 27-44.
Kothari, S.P., A.J. Leone and C.E. Wasley, 2005. Performance matched discretionary accrual measures. J. Account. Econ., 39: 163-197.

Lieberman, M. and N. Balasubramanian, 2007. Measuring value creation and its distribution among stakeholders of the firm. J. Acad. Manage. Sci., 1: $1-43$.

Mendes-Da-Silva, W. and A.L. de Lira, 2004. The voluntary disclosure of financial information on the internet and firm value effect in companies across Latin America. SSRN. Electro. J., 1: 1-25.

Mutiva, J.M., A.H. Ahmed and J.W. Muiruri-Ndirangu, 2015. The relationship between voluntary disclosure and financial performance of companies quoted at the Nairobi securities exchange. Intl. J. Managerial Stud. Res., 3: 171-195.

Nyamongo, J.M., 2017. Relationship between Voluntary Disclosure and value of Listed Insurance Companies in Kenya. Ph.D Thesis, United States International University Africa, Nairobi, Kenya, East Africa.

Paminto, U.H.A., 2015. Corporate Governance and firm value: The mediating effect of financial performance and firm risk. Corporate Governance, 7: 18-24.

Verrecchia, R.E., 2001. Essays on disclosure. J. Accounting Econ., 32: 97-180. 